\title{
Airborne molecules released from male mouse urine affect female exploratory behavior
}

\section{Marco Redaelli ${ }^{1,2}$, Alessandro Orsetti ${ }^{3}$, Giuseppe Zagotto $^{3}$, Andrea Cavaggioni ${ }^{1}$ and Carla Mucignat-Caretta ${ }^{1,2 *}$}

${ }^{1}$ Department of Molecular Medicine, University of Padova, Padova, Italy

${ }^{2}$ National Institute of Biostructures and Biosystems, Rome, Italy

${ }^{3}$ Department of Pharmaceutical Sciences, University of Padova, Padova, Italy

Edited by:

Lukasz Lech Stelinski, University of Florida, USA

\section{Reviewed by:}

Matthieu Keller, Centre National de

la Recherche Scientifique, France

Heather Maclntosh Schellinck,

Dalhousie University, Canada

\section{*Correspondence:}

Carla Mucignat-Caretta, Department of Molecular Medicine, University of Padova, Via Marzolo 3, 35131

Padova, Italy

e-mail: carla.mucignat@unipd.it
Male mouse urine delivers a wide range of molecules which may be involved in intraspecific chemical communication. These include the Major Urinary Proteins (MUP) which bind volatile odorant molecules and slowly release them from urine marks. The aim of this work is to evaluate the role of volatile molecules in eliciting exploratory behavior, in comparison to MUP. Female mice were exposed to male mouse urine, either diluted or not, or to MUP stripped of ligands. Gas chromatography and mass spectrometry of the stimuli were performed to verify the presence and identify the odorant molecules in urine and to assess the absence of MUP ligands. The exploratory behavior of adult female mice was analyzed in a cage, in the presence of two stimuli on opposite sides, but preventing direct contact with them. Four stimuli were presented in pairs: adult male mouse urine, MUP stripped of ligands, urine diluted 100 times and water as control. The results show that adult female mice explore urine, as little as $150 \mathrm{nl}$, but do not explore MUP stripped of ligands. These data show that male urine airborne molecules, effective at very low doses, mediate initial stimulus exploration by female mice.

Keywords: MUP, odorants, urine, mice, olfaction, behavior, chemical signals

\section{INTRODUCTION}

Most mammals have developed chemosensory systems which are involved in social communication, using chemical signals excreted in urine, feces, milk, saliva, or sweat (Wyatt, 2010; Apps, 2013; Liberles, 2014). Molecules possibly acting as intraspecific chemical signals were identified in mouse urine (Novotny et al., 1990; Mucignat-Caretta et al., 1995; Hurst et al., 2001) and in other body secretions (Rock et al., 2006; Haga et al., 2010); they may modulate the behavior or the neuroendocrine axis of conspecifics, supporting the management of social relationships.

Major Urinary Proteins (MUP) belong to the lipocalin family (Cavaggioni et al., 1987). They are excreted in the urine of adult mice and are characterized by a wide range of isoforms (Cavaggioni and Mucignat-Caretta, 2000), some of which are specific for either sex and may transmit information regarding individual identity (Sharrow et al., 2002; Armstrong et al., 2005). MUP bind ligands (Bacchini et al., 1992; Böcskei et al., 1992; Robertson et al., 1993) and delay their release from the urine spot (Hurst et al., 1998). In the last years, the role of MUP in intraspecific communication was explored. MUP polymorphism apparently provides information concerning species, gender, and social status of the releaser: they may influence the individual recognition of other males (Hurst et al., 2001) or females (Stockley et al., 2013) and can promote aggressive behavior (Chamero et al., 2007). MUP are also involved in some VNO-mediated responses, such as the puberty onset acceleration (Mucignat-Caretta et al., 1995), estrus stimulation (Marchlewska-Koj et al., 2000), or ovulation (Morè, 2006).

A complementary, non-overlapping function has been suggested for volatile molecules and urinary proteins, as the former may act as olfactory flags for the presence of MUP (MucignatCaretta and Caretta, 1999a), while non-volatile chemosignals may act as natural reinforcers that induce conditioned place preference (Martínez-Ricós et al., 2007). In the majority of cases, the two different components of mice chemosignals, volatile, and non-volatile, have been studied independently, so the contribution of each component in the initial phase of attention orienting to the chemical stimuli remains unclear. Male urinary chemosignals are attractive to adult females, but repel adult males (Mucignat-Caretta et al., 1998; Mucignat-Caretta and Caretta, 1999b; Mucignat-Caretta, 2002). There is some evidence that single volatile molecules, the farnesenes, may attract female mice, but at a concentration at least double the urinary concentration (Jemiolo et al., 1991). However, the role of volatile molecules in mediating initial alert and in prompting stimulus exploration, and their relative potency compared to the urinary proteins, is still unclear, too.

The aim of the present work is to determine the potency of naturally occurring urinary molecules in attracting female mice for stimulus exploration. To elucidate the contribution of airborne urinary molecules in eliciting exploration, we analyzed the exploratory behavior of adult estrus females, exposed either to the volatile phase of male mouse urine or to MUP stripped of ligands 
(sMUP). In order to provide a comparison between the quantity of volatile molecules and the urinary proteins present in a urine drop, we presented four set of stimuli to female mice, and evaluated the relative attraction properties, by comparing stimuli at a dosage similar to what is normally found in mice urine drops, or at a dosage scaled down 100 times. We choose this quantity since it was already demonstrated that this is the minimal dose of urine required to modify puberty in female mice (Drickamer, 1984). We wished to determine if this quantity of urine would be sufficient to also induce behavioral attraction.

\section{MATERIALS AND METHODS ANIMALS}

Experiments were carried out according to the Italian law on animal experiments (L. 116/92). Twenty-five 3-months old CD-1 mice, Mus musculus, were used, that is 12 males for urine collection, and 13 females for behavioral testing. To provide a natural pheromonal and social context, the mice were born and reared with both parents and littermates, in standard polycarbonate cages $(42 \times 26 \times 15 \mathrm{~cm})$, with water and food pellets ad libitum (Altromin, Rieper, Bolzano). The mice were weaned at 21 days of age and housed six per cage with same sex and age cage-mates, up to the beginning of the experiment. Cage bedding was made of wood shavings changed once a week. The temperature was 25 $\pm 1^{\circ} \mathrm{C}$, with $60 \%$ relative humidity and six air renewals per hour. The light cycle, with $12 \mathrm{~h}$ light on, started at 05:00 am.

\section{URINE COLLECTION}

Two groups of six male mice were used as urine donors. They were isolated 1 month before urine collection. Each mouse was singly placed in a cage with a mesh grid fixed 2 centimeters above the cage floor and the urine was collected from the floor with a pipette immediately after voiding. During the daily collection $(1 \mathrm{~h})$ the urine was kept over ice and then frozen at $-20^{\circ} \mathrm{C}$ for storage. Urine collection continued for 10 days, afterwards the urine was pooled according to the two mouse groups; the protein concentration $(10 \mathrm{mg} / \mathrm{ml})$ was determined with colorimetric Bradford assay and frozen in aliquots.

\section{MUP PURIFICATION}

MUP was purified from male mouse urine with an ammonium sulfate (Merck, USA) differential precipitation (50-70\% at $0^{\circ} \mathrm{C}$ ), followed by extensive dialysis against $5.5 \mathrm{mM} \mathrm{NaCl}$ (molecular mass membrane cut-off $10^{4} \mathrm{Da}$ ). The MUP solution was extracted three times with one volume of dichloromethane to remove the volatile compounds, the organic phase was discarded and the water phase was stored at $-20^{\circ} \mathrm{C}$ at the concentration of $10 \mathrm{mg} / \mathrm{ml}$. This procedure already proved effective for isolating chemosignals active in inducing estrus (Marchlewska-Koj et al., 2000) and ovulation (Morè, 2006).

\section{GAS-CHROMATOGRAPHY}

Solid phase micro extraction (SPME) of the headspace was followed by gas-chromatography/mass spectrometry (GC/MS) and gas-chromatography/flame ionization detection (GC/FID) for chemical identification or for ion abundance determination, according to Cavaggioni et al. (2006). Briefly, the polydimethylsiloxane SPME fiber, $100 \mu \mathrm{m}$ thick (Supelco, SigmaAldrich Co., USA), was preconditioned at $280^{\circ} \mathrm{C}$ for $60 \mathrm{~min}$ in constant He flux. It was then inserted through the cork in the vial containing $15 \mu \mathrm{l}$ of urine or MUP and left to sample the head-space at $45^{\circ} \mathrm{C}$ for $45 \mathrm{~min}$.

The sample was injected either in a GC/MS or in a GC/FID. The split/splitless injection was in a VA-5, $30 \mathrm{~m}$ long capillary column, $0.25 \mathrm{~mm}$ in diameter, coated with a phenylmethylpolysiloxane film $0.25 \mu \mathrm{m}$ thick (Varian, Palo Alto, CA-USA). The MS was in full-scan mode in the $m / z$ range between 20 and 800 . The GC temperature program was: $15 \mathrm{~min}$ at $35^{\circ} \mathrm{C}$, a ramp of $3^{\circ} \mathrm{C} / \mathrm{min}$ up to $60^{\circ} \mathrm{C}$, holding at $60^{\circ} \mathrm{C}$ for $5 \mathrm{~min}$, a ramp of $10^{\circ} \mathrm{C} / \mathrm{min}$ up to $150^{\circ} \mathrm{C}$, holding for $1 \mathrm{~min}$, a ramp of $25^{\circ} \mathrm{C} / \mathrm{min}$ up to $290^{\circ} \mathrm{C}$, holding for $20 \mathrm{~min}$ (Cavaggioni et al., 2006). Identification of compounds was based on the retention time of standards and probability-matching of mass spectra using a computer library (NIST, www.nist.gov, USA).

\section{CYCLE MONITORING}

The estrus cycle of female mice was monitored for 10 days by taking the vaginal smear once a day. The smears were observed at the light microscope in phase contrast to evaluate the typical percentage of cells for each phase. In order to synchronize the estrus cycle, during the 10 days, $100 \mu$ l of male mouse urine pooled from the first group of donors were sprayed over the bedding in the cage twice a day (9.00-15.00). After the 10 days allowed for estrus synchronization, the females were checked for subsequent estrus phases, during which the behavioral tests were done.

\section{BEHAVIORAL TEST}

Thirteen female mice were tested while in their estrus phase. The stimuli were presented to mice in a polycarbonate cage $(46 \times 26 \times 20 \mathrm{~cm})$, in a dedicated room (temperature $20 \pm 2^{\circ} \mathrm{C}$ and $72 \%$ relative humidity).

The mice were taken from their home cage and tested in the experimental cage whose floor was lined with Bench Guard (Bibby Sterilin, Staffordshire, UK). The stimuli (15 $\mu$ l) were spotted on a 1 square centimeter filter paper (Superfiltro, Milano, Italy), affixed with double-sided adhesive tape in the middle of the shorter walls $(26 \mathrm{~cm})$ of the cage, $15 \mathrm{~cm}$ above the floor, to prevent direct contact of the mouse nose with the stimuli.

Four experiments were conducted, each one lasting 6 min: (1) in the first, one side of the cage presented $15 \mu \mathrm{l}$ of male urine and the other $15 \mu \mathrm{l}$ of water; (2) in the second, one side of the cage presented $15 \mu \mathrm{l}$ of sMUP and the other $15 \mu \mathrm{l}$ of water; (3) in the third, one side of the cage presented $15 \mu \mathrm{l}$ of male urine and the other $15 \mu \mathrm{l}$ of sMUP; (4) in the fourth, one side of the cage presented $15 \mu \mathrm{l}$ of male urine diluted 100 times in distilled water and the other $15 \mu \mathrm{l}$ of sMUP. The four experiments were performed each in 1 of 4 non-consecutive days, according to the female estrus phase. Within each day, a single pair of stimuli was tested.

During each experiment two variables were recorded: the number of rearings (placing the two forepaws on the wall of the stimulus side) and the latency to the first rearing. The behavioral data were analyzed using Statistica 5.0 (StatSoft, inc., Tulsa, 
USA) for MS Windows. The number of rearings and latency to the first rearing were separately analyzed for each test with OneWay ANOVA. Results were considered statistically significant for $\mathrm{p}<0.05$.

\section{RESULTS}

\section{GAS-CHROMATOGRAPHY}

The headspace GC/MS and GC/FID analysis of the air above urine showed a chemical profile (Figure 1A) similar to those reported in the literature (Cavaggioni et al., 2006). The major volatile molecules present in male urine were identified as: 2,4-dehydro-exo-brevicomin, 2-sec-butyl-4,5-dihydrothiazole, 2,4-dimethyl-phenol, 4-ethyl-phenol, indole, 2-butyl-1-octanol, 2-ethyl-1-decanol. The analysis of the sMUP sample did not detect volatile compounds in the headspace (Figure 1B).

\section{BEHAVIORAL TEST}

The data showed a statistically significant increase in the number of rearings on the wall hosting the urine, compared to those hosting water $\left[F_{(1,12)}=21.38, p<0.001-\right.$ Figure $\left.2 \mathrm{~A}\right]$ or sMUP $\left[F_{(1,12)}=101.57, p<0.001\right.$-Figure $\left.2 \mathrm{C}\right]$, while no difference between water and sMUP was observed (Figure 2B). Urine diluted 100 times induced more rearings than sMUP $\left[F_{(1,12)}=17.64, p<0.005\right.$-Figure 2D $]$.

The latency to the first rearing was significantly shorter in the side hosting urine against water $\left[F_{(1,12)}=7.78, p<0.05-\right.$ Figure 3A $]$ or sMUP $\left[F_{(1,12)}=22.47, p<0.001\right.$-Figure 3C], while no difference between water and sMUP was observed (Figure 3B). Urine diluted 100 times elicited the first rearing faster than $\operatorname{sMUP}\left[F_{(1,12)}=5.66, p<0.05\right.$-Figure 3D $]$.

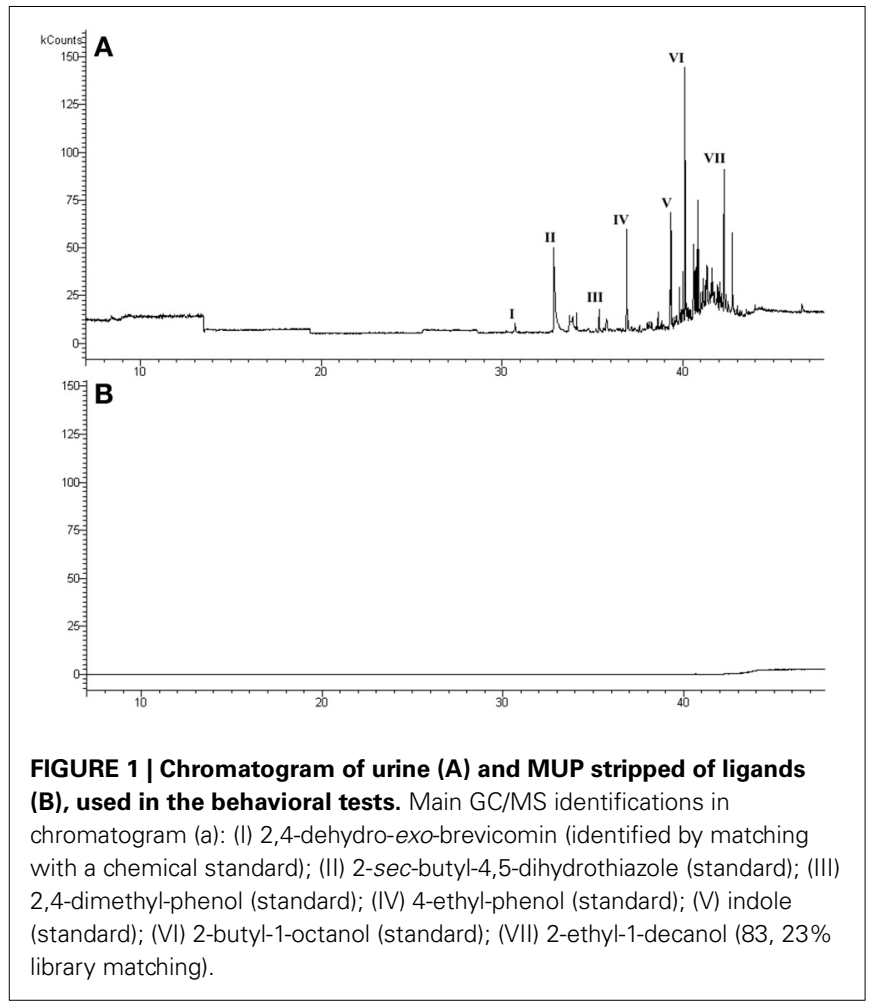

\section{DISCUSSION}

Mice behavior is strongly affected by complex chemosensory information which involves both volatile molecules and urinary proteins. These stimuli differentially activate the main and accessory olfactory systems, inducing selective responses to urine
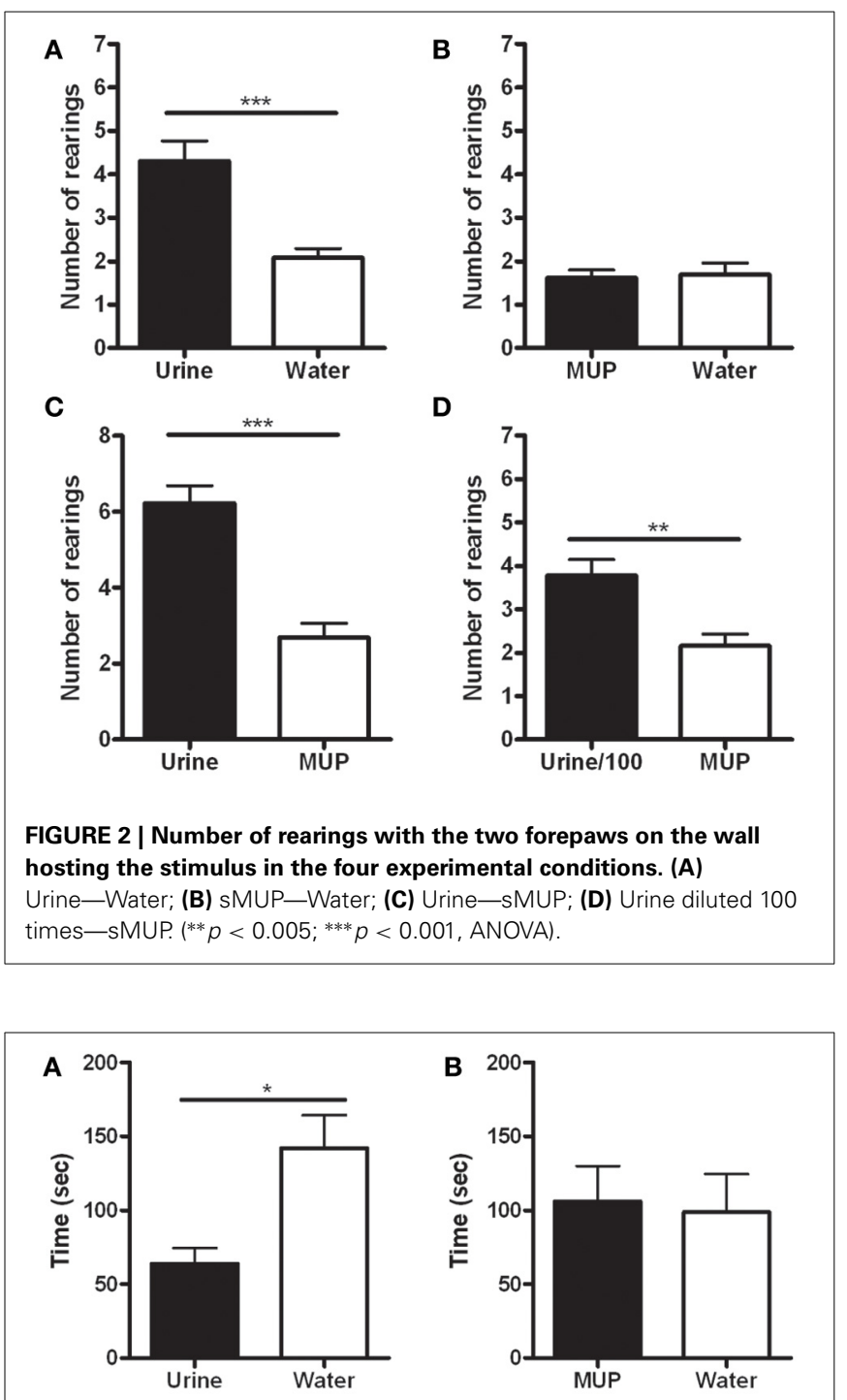

C
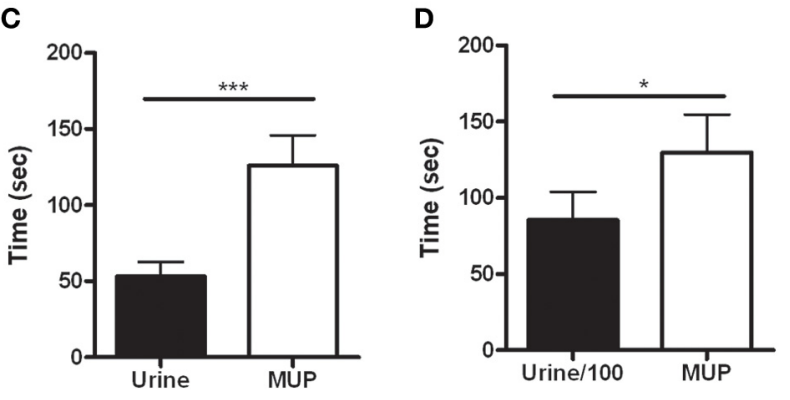

FIGURE 3 | Latency to the first rearing in the four experimental conditions. (A) Urine-Water; (B) sMUP-Water; (C) Urine-sMUP; (D) Urine diluted 100 times-sMUP. $\left({ }^{*} p<0.05\right.$; ${ }^{* *} p<0.001$, ANOVA). 
from different donors (Veyrac et al., 2011). The initial differential processing of chemicals by the main and accessory olfactory systems is partly compensated by the high degree of interaction between their downstream projection areas (Kang et al., 2009; Mucignat-Caretta et al., 2012), so that chemosignals may lead to complex effects. In the present paper we analyzed the exploratory behavior of estrus female mice exposed to the smell of adult male mouse urine, sMUP, or water. The SPME GC/MS and GC/FID analysis showed the absence of detectable compounds in the headspace over the sMUP that was used, in particular the known chemical compounds influencing female mouse behavior (Jemiolo et al., 1991; Mucignat-Caretta, 2002), by acting through the vomeronasal organ (Leinders-Zufall et al., 2000).

The chemical analysis of adult male mouse urine, used as a stimulus, revealed the typical pattern of volatiles described in the literature (Novotny et al., 1990; Cavaggioni et al., 2006), by showing some major peaks that were identified as male-specific substances. Some of these molecules are already known to modulate mice behavior (Novotny et al., 1985, 1990).

Estrus female mice are attracted by male urine even in hostile environments (Mucignat-Caretta et al., 1998; Mucignat-Caretta, 2002). The present behavioral tests showed that estrus female mice are attracted to the area containing the male urine, even in a small dosage (equal to $0.15 \mathrm{ml}$, or $150 \mathrm{nl}$, of urine). This behaviorally active dosage is reminiscent of the minimal quantity of urine needed to modulate the neuroendocrine axis of female mice, since a similar amount of male urine was sufficient for puberty acceleration (Drickamer, 1984). As a urine drop weight ranges between 11 and $17 \mathrm{mg}$ (Mucignat-Caretta et al., 2004), the size of the urine spot we used here $(15 \mu l)$ is within the range of physiological drops voided by intact adult CD1 male mice, while the quantity of urine active in inducing behavioral activation may be 100 times smaller. Since contact with the stimuli was prevented by placing them out of reach, the attraction to the stimulus should be mediated by the volatile molecules that, in this context, are sufficient to attract females. On the other hand, a much larger quantity of sMUP (equivalent to $15 \mu \mathrm{l}$ of urine) cannot induce attraction. The lack of exploratory behavior in the area spotted with sMUP parallels the lack of exploratory behavior toward water. These results suggest that sMUP is not sufficient to attract estrus female mice from a distance, while a fraction of a normal micturition act definitely may do so.

Therefore, it appears that the initial proceptive behavior that consists of stimulus exploration must be driven by chemical signals released by the urinary trace, while the following phases, either behavioral or neuroendocrine, may bring a more complex chemical signaling system into play, involving also a protein component. These data highlight the importance of the co-occurrence of both signals, odorant, and proteins, which represent a complex chemosignaling system, evolved to efficiently manage social contacts in mice. Moreover, they introduce some metrics in evaluating the magnitude of natural stimuli that are effective in modulating mice behavior: this may be relevant when studying the functional properties of the receptors involved in chemosignal transduction, whose response properties may be related to the concentration of the stimuli (Leinders-Zufall et al., 2000).

\section{ACKNOWLEDGMENT}

This work was supported by PRIN 2010-2011 (grant no. 2010599KBR_008) to Carla Mucignat-Caretta.

\section{REFERENCES}

Apps, P. J. (2013). Are mammal olfactory signals hiding right under our noses? Naturwissenschaften 100, 487-506. doi: 10.1007/s00114-013-1054-1

Armstrong, S. D., Robertson, D. H. L., Cheetham, S. A., Hurst, J. L., and Beynon, R. J. (2005). Structural and functional differences in isoforms of mouse major urinary proteins: a male-specific protein that preferentially binds a male pheromone. Biochem. J. 391, 343-350. doi: 10.1042/BJ200 50404

Bacchini, A., Gaetani, E., and Cavaggioni, A. (1992). Pheromone binding-proteins of the mouse, Mus-musculus. Experientia 48, 419-421. doi: 10.1007/BF019 23448

Böcskei, Z., Groom, C. R., Flower, D. R., Wright, C. E., Phillips, S. E., Cavaggioni, A., et al. (1992). Pheromone binding to two rodent urinary proteins revealed by X-ray crystallography. Nature 360, 186-188. doi: 10.1038/360186a0

Cavaggioni, A., and Mucignat-Caretta, C. (2000). Major urinary proteins, alpha(2U)-globulins and aphrodisin. Biochim. Biophys. Acta 1482, 218-228. doi: $10.1016 /$ S0167-4838(00)00149-7

Cavaggioni, A., Mucignat-Caretta, C., Redaelli, M., and Zagotto, G. (2006). The scent of urine spots of male mice, Mus-musculus: changes in chemical composition over time. Rapid Comm. Mass Spectrom. 20, 3741-3746. doi: $10.1002 / \mathrm{rcm} .2789$

Cavaggioni, A., Sorbi, R. T., Keen, J. N., Pappin, D. J., and Findlay, J. B. (1987). Homology between the pyrazine-binding protein from nasal mucosa and major urinary proteins. FEBS Lett. 212, 225-228. doi: 10.1016/0014-5793(87)81349-2

Chamero, P., Marton, T. F., Logan, D. W., Flanagan, K., Cruz, J. R., Saghatelian, A., et al. (2007). Identification of protein pheromones that promote aggressive behaviour. Nature 450, 899-902. doi: 10.1038/nature05997

Drickamer, L. C. (1984). Effects of very small doses of urine on acceleration and delay of sexual maturation in female house mice. J. Reprod. Fertil. 71, 475-477. doi: $10.1530 /$ jrf.0.0710475

Haga, S., Hattori, T., Sato, T., Sato, K., Matsuda, S., Kobayakawa, R., et al. (2010). The male mouse pheromone ESP1 enhances female sexual receptive behaviour through a specific vomeronasal receptor. Nature 466, 118-124. doi: 10.1038/nature09142

Hurst, J. L., Payne, C. E., Nevison, C. M., Marie, A. D., Humphries, R. E., Robertson, D. H., et al. (2001). Individual recognition in mice mediated by major urinary proteins. Nature 414, 631-634. doi: 10.1038/414631a

Hurst, J. L., Robertson, D. H. L., Tolladay, U., and Beynon, R. J. (1998). Proteins in urine scent marks of male house mice extend the longevity of olfactory signals. Anim. Behav. 55, 1289-1297. doi: 10.1006/anbe.1997.0650

Jemiolo, B., Xie, T. M., and Novotny, M. (1991). Socio-sexual olfactory preference in female mice: attractiveness of synthetic chemosignals. Physiol. Behav. 50, 1119-1122. doi: 10.1016/0031-9384(91)90570-E

Kang, N., Baum, M. J., and Cherry, J. A. (2009). A direct main olfactory bulb projection to the 'vomeronasal' amygdala in female mice selectively responds to volatile pheromones from males. Eur. J. Neurosci. 29, 624-634. doi: 10.1111/j.1460-9568.2009.06638.x

Leinders-Zufall, T., Lane, A. P., Puche, A. C., Ma, W., Novotny, M. V., Shipley, M. T., et al. (2000). Ultrasensitive pheromone detection by mammalian vomeronasal neurons. Nature 405, 792-796. doi: 10.1038/35015572

Liberles, S. D. (2014). Mammalian pheromones. Ann. Rev. Physiol. 76, 151-175. doi: 10.1146/annurev-physiol-021113-170334

Marchlewska-Koj, A., Cavaggioni, A., Mucignat-Caretta, C., and Olejniczak, P. (2000). Stimulation of estrus in female mice by male urinary proteins. J. Chem. Ecol. 26, 2355-2366. doi: 10.1023/A:1005578911652

Martínez-Ricós, J., Agustín-Pavón, C., Lanuza, E., and Martínez-García, F. (2007). Intraspecific communication through chemical signals in female mice: reinforcing properties of involatile male sexual pheromones. Chem. Senses 32, 139-148. doi: $10.1093 /$ chemse/bj1039

Morè, L. (2006). Mouse urinary proteins trigger ovulation via the vomeronasal organ. Chem. Senses 31, 393-401. doi: 10.1093/chemse/bjj043

Mucignat-Caretta, C. (2002). Modulation of exploratory behavior in female mice by protein-borne male urinary molecules. J. Chem. Ecol. 28, 1853-1863. doi: 10.1023/A:1020521420271 
Mucignat-Caretta, C., Bondì, M., and Caretta, A. (2004). Endocrine status affects bladder size and postvoid residual urinary volume in mice. Horm. Behav. 46, 11-18. doi: 10.1016/j.yhbeh.2004.02.004

Mucignat-Caretta, C., and Caretta, A. (1999a). "Protein-bound odorants as flags of male mouse presence," in Advances in Chemical Signals in Vertebrates, eds R. E. Johnston, D. Muller-Schwarze, and P. Sorensen (New York, NY: Plenum Press), 149-162.

Mucignat-Caretta, C., and Caretta, A. (1999b). Urinary chemical cues affect light avoidance behaviour in male laboratory mice, Mus musculus. Anim. Behav. 57, 765-769. doi: 10.1006/anbe.1998.1023

Mucignat-Caretta, C., Caretta, A., and Baldini, E. (1998). Protein-bound male urinary pheromones: differential responses according to age and gender. Chem. Senses 23, 67-70. doi: 10.1093/chemse/23.1.67

Mucignat-Caretta, C., Caretta, A., and Cavaggioni, A. (1995). Acceleration of puberty onset in female mice by male urinary proteins. J. Physiol. 486, 517-522.

Mucignat-Caretta, C., Redaelli, M., and Caretta, A. (2012). One nose, one brain: contribution of the main and accessory olfactory system to chemosensation. Front. Neuroanat. 6:46 doi: 10.3389/fnana.2012.00046

Novotny, M., Harvey, S., Jemiolo, B., and Alberts, J. (1985). Synthetic pheromones that promote inter-male aggression in mice. Proc. Natl. Acad. Sci. U.S.A. 82, 2059-2061. doi: 10.1073/pnas.82.7.2059

Novotny, M., Jemiolo, B., and Harvey, S. (1990). Chemistry of male dominance in the house mouse, Mus domesticus. Experientia 46, 109-113. doi: 10.1007/BF01955433

Robertson, D., Beynon, R., and Evershed, R. (1993). Extraction, characterization, and binding analysis of two pheromonally active ligands associated with major urinary protein of house mouse (Mus musculus). J. Chem. Ecol. 19, 1405-1416. doi: 10.1007/BF00984885

Rock, F., Mueller, S., Weimar, U., Rammensee, H. G., and Overath, P. (2006). Comparative analysis of volatile constituents from mice and their urine. J. Chem. Ecol. 32, 1333-1346. doi: 10.1007/s10886-006-9091-2
Sharrow, S. D., Vaughn, J. L., Zidek, L., Novotny, M. V., and Stone, M. J. (2002). Pheromone binding by polymorphic mouse major urinary proteins. Protein Sci. 11, 2247-2256. doi: 10.1110/ps.0204202

Stockley, P., Bottell, L., and Hurst, J. L. (2013). Wake up and smell the conflict: odour signals in female competition. Philos. Trans. R. Soc. Lond. B Biol. Sci. 368 , 20130082. doi: 10.1098/rstb.2013.0082

Veyrac, A., Wang, G., Baum, M. J., and Bakker, J. (2011). The main and accessory olfactory systems of female mice are activated differentially by dominant versus subordinate male urinary odors. Brain Res. 1402, 20-29. doi: 10.1016/j.brainres.2011.05.035

Wyatt, T. D. (2010). Pheromones and signature mixtures: defining species-wide signals and variable cues for identity in both invertebrates and vertebrates. J. Comp. Physiol. A Neuroethol. Sens. Neural Behav. Physiol. 196, 685-700. doi: 10.1007/s00359-010-0564-y

Conflict of Interest Statement: The authors declare that the research was conducted in the absence of any commercial or financial relationships that could be construed as a potential conflict of interest.

Received: 14 April 2014; accepted: 09 June 2014; published online: 25 June 2014.

Citation: Redaelli M, Orsetti A, Zagotto G, Cavaggioni A and Mucignat-Caretta C (2014) Airborne molecules released from male mouse urine affect female exploratory behavior. Front. Ecol. Evol. 2:28. doi: 10.3389/fevo.2014.00028

This article was submitted to Chemical Ecology, a section of the journal Frontiers in Ecology and Evolution.

Copyright (C) 2014 Redaelli, Orsetti, Zagotto, Cavaggioni and Mucignat-Caretta. This is an open-access article distributed under the terms of the Creative Commons Attribution License (CC BY). The use, distribution or reproduction in other forums is permitted, provided the original author(s) or licensor are credited and that the original publication in this journal is cited, in accordance with accepted academic practice. No use, distribution or reproduction is permitted which does not comply with these terms. 